
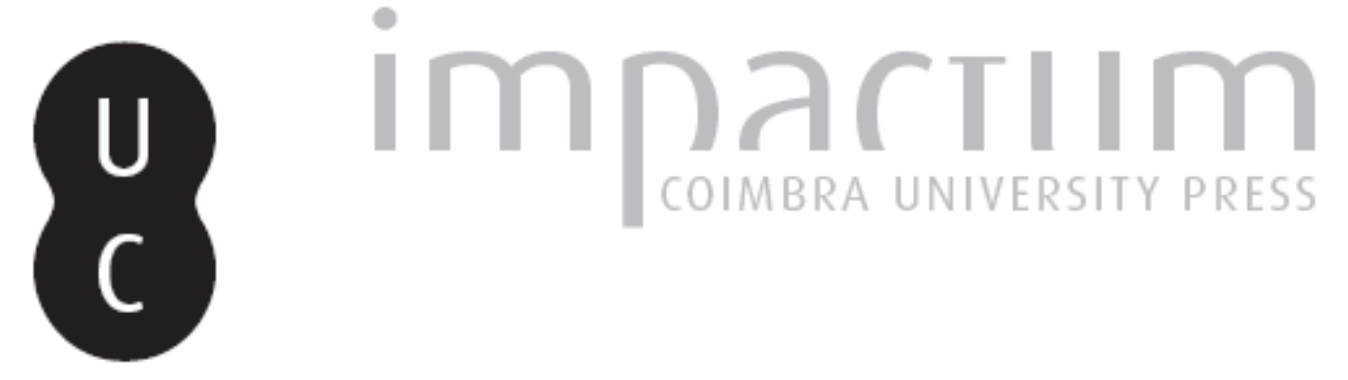

\title{
Developing the Good itself by itself: critical strategies in Plato's Euthydemus
}

Autor(es): $\quad$ McCabe, Mary Margaret

Publicado por: Imprensa da Universidade de Coimbra

URL persistente:

URI:http://hdl.handle.net/10316.2/42269

DOI:

DOI:https://doi.org/10.14195/2183-4105_2_3

Accessed : $\quad$ 26-Apr-2023 14:46:48

A navegação consulta e descarregamento dos títulos inseridos nas Bibliotecas Digitais UC Digitalis, UC Pombalina e UC Impactum, pressupõem a aceitação plena e sem reservas dos Termos e Condições de Uso destas Bibliotecas Digitais, disponíveis em https://digitalis.uc.pt/pt-pt/termos.

Conforme exposto nos referidos Termos e Condições de Uso, o descarregamento de títulos de acesso restrito requer uma licença válida de autorização devendo o utilizador aceder ao(s) documento(s) a partir de um endereço de IP da instituição detentora da supramencionada licença.

Ao utilizador é apenas permitido o descarregamento para uso pessoal, pelo que o emprego do(s) título(s) descarregado(s) para outro fim, designadamente comercial, carece de autorização do respetivo autor ou editor da obra.

Na medida em que todas as obras da UC Digitalis se encontram protegidas pelo Código do Direito de Autor e Direitos Conexos e demais legislação aplicável, toda a cópia, parcial ou total, deste documento, nos casos em que é legalmente admitida, deverá conter ou fazer-se acompanhar por este aviso.

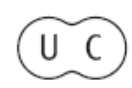




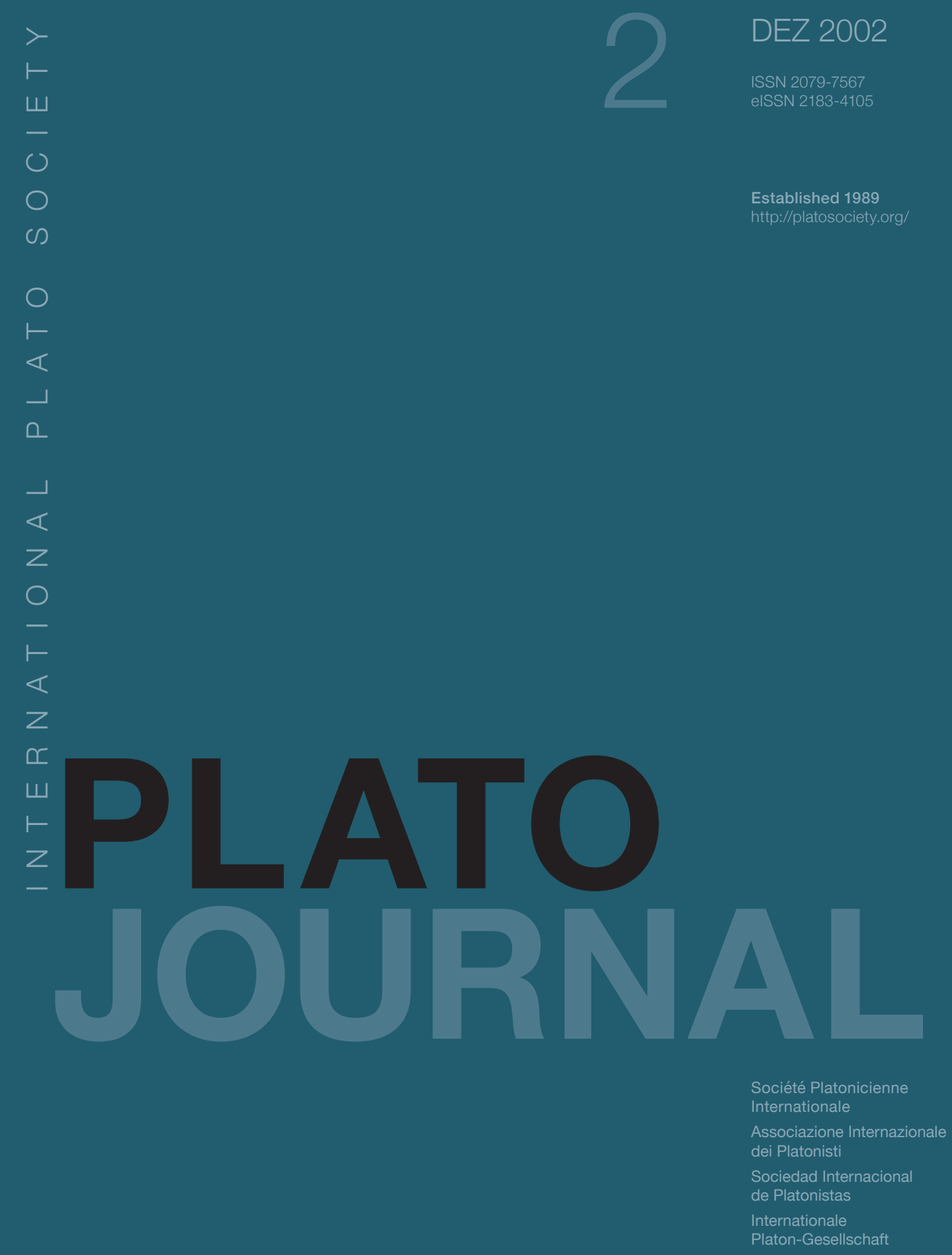




\title{
Developing the Good itself by itself: Critical Strategies in Plato's Euthydemus
}

\author{
McCABE, Mary Margaret, in 2. Plato 2
}

(2002) , [En ligne] , January 2002

\begin{abstract}
Did Plato change his mind? This has become a topical question once again, especially after the publication of two books which dispute some received wisdom about the 'Socratic' dialogues [1]. The received wisdom imagined that we might distinguish between an early period of Platonic thought and the middle period dialogues. In particular (many still suppose), between dialogues such as the Protagoras or the Laches and the Phaedo or the Republic we can see Plato changing his mind about metaphysics (are there transcendent forms?) and psychology (is the soul simple or complex?). The popular diagnosis of this - especially since Vlastos defended it in detail [2] - was that Plato changed his mind because he began to move away from the influence of the historical Socrates, so that the middle period represented a break from the Socratic view.
\end{abstract}

This stark view of Platonic development began to blur at the same time as a different set of questions came into focus, about how one should read the dialogues. It is now de rigueur to observe that the character of Socrates in the early dialogues is an emphatically fictional figure. To represent Socrates as a strictly historical personage (whether as having actually said these things or as having been committed to things like this) is to miss a great deal of the complex literary features of the early dialogues. This, in turn, is to miss the way in which Plato exploits literary technique to make philosophical points. Perhaps Socrates is not - ever or always - marked out for special, pietistic attention, but, rather, engages us in a complex piece of interpretation, itself to provoke philosophical reflection [3].

These point, surely, are well taken. When once we attend to the detail even of the dialogues supposed to have been written early in Plato's career, the subtlety of their composition must dispel for ever not only what Lindsay Judson once called the 'Hansard' view of a Platonic dialogue (as an accurate record of some historical encounter) but also the pietistic story which has this Socrates as the hero of a philosophical adventure. Instead, surely, the first task of any interpreter should be to give a full account of each dialogue as a whole - since it is only in such a way that its complexity can be both revealed and exploited to philosophical ends.

Nonetheless, that dialogue-by-dialogue approach cannot exhaust our interpretative strategies, not least because Plato himself seems regularly to use literary weaponry to make connections between dialogues. Consider, for example, the reference to the Meno at the opening of the Phaedo's discussion of recollection (73a-b). This precedes the preliminary discussion of the ordinary phenomenon of remembering and, in reminding us of another dialogue, provokes in the reader the very phenomenon that Socrates is seeking to describe - it also, for my money, invites us to compare and contrast the philosophical problems addressed in the two passages. Or, for a less ostentatious example, consider the running theme of the sticks and the stones. At Phaedo 74b, Parmenides 129d

and Sophist 246a the use of the same examples invites the attentive reader to wonder how these different puzzles about particulars are related.

Intertextuality - whether it is explicit, as in the Phaedo example, or allusive, as in the case of the sticks and stones - is, however, a complicated business; and it brings us back to the question of Plato's changing mind. These cross-references and allusions may, of course, simply function as a foot-noting mechanism: when we read this passage, we should recall some other passage that makes a related point. But they may serve not merely to remind but also to contrast: and in this, their philosophical function is a critical one. (This point, of course, is not unfamiliar to Plato himself: recall the critical function of recollection introduced at Phaedo 74a). In that case the direction of the reference is, we might say, backwards. The reference invites us to think about something with which we may already be familiar, and to wonder whether - in the context of the passage we are presently dealing with - we have here the same point, or one which is somehow different; and if it is different, of course, we are invited to wonder whether the two points cohere.

A different view would be that intertextual reference does not look backwards but forwards: hence Kahn's 'proleptic' or 'ingressive' reading of the early and middle dialogues [4].

The thought here is that there is a single body of theory beneath the dialogues of the early and middle periods; but it is unveiled slowly, anticipated by the dialogues beforethe Republic, whose conclusions in the Republic are only revealed once the reader has been adequately educated in the preliminaries. 
When one dialogue seems to refer to another, there is no obvious means of determining what the direction of the reference is, nor, therefore, of adjudicating between a case of prolepsis, and a case of back reference. Indeed, there may be occasions where even trying to make such a decision is either pointless or mistaken: some passages may be verbally connected in order to make complementary points []ㅡ. So, we should concede, intertextual reference just is complex in these ways, and Plato's intentions only as clear to us as he himself will allow.

One might, of course, mount a general argument against prolepsis, namely that it promotes an unduly expensive view of Plato's deliberate intentions, not to mention his developed theory, when he set about writing all the works up to and including the Republic. Instead, a more piecemeal account of the relations between dialogues might support a more piecemeal and - if I may so call it metaleptic view of intertextuality: one that reveals critical, retrogressive, relations between dialogues. But even if metalepsis is thought to be a thriftier view of Plato's intentions - since it does not require him to be engaging on huge projects of deliberate manipulation of his reader - there is no prima facie reason for not allowing at least some prolepsis across the same counter. The payoff - that it takes us far from the Hansard view - may be worth it, after all.

But there is, nonetheless, something at stake in the choice between the two accounts. For, as Kahn concedes, prolepsis treats the grand plan of the early-middle sequence of dialogues as unitarian. It requires, therefore, that there should be, or that Plato supposed there to be, consistent and coherent theories to underlie it, so that it is somehow all of the same piece, educationally. This does not, of course, imply that every doctrine or theory of the Republic is implicit in, for example, the Euthyphro. It does, however, demand that consistency between one dialogue and another is a constraint on the grand plan. We should not go too far. Plato may have admitted inconsistencies unwittingly; and even if there is a grand plan, Plato could not have written all the dialogues at once, so we may expect some areas where the detail does not fit. But to sustain the proleptic account the grand plan itself, whatever it may be, must aspire to be relatively stable and free of inconsistencies.

The metaleptic view has no such commitment to consistency. On the contrary, it is a virtue of this view that intertextual material may set one passage against another and, in so doing, allow one view to be criticised by another. This attaches metalepsis closely to a developmentalist account of Plato's philosophy, that it is characterised by changes of mind and critical reflection. This in turn may allow (although it need not require) a kind of open-endedness that unitarian accounts must eschew. If all the dialogues before the Republic lead us to the theories found there, any puzzlement they may display will be purely protreptic, and not a part of the working philosophy going on there. If, on the other hand, later dialogues serve to offer critical reflection on earlier, then the critique itself may assume no immediate solution: aporiai may be genuine, and none the worse for that. This Plato is a self-critical theorist, who uses intertextual reference not merely to allude to, but to provoke reflection in one text on another.

This thought, after all, has been around a long time. In the recent debates about development and unitarianism, most of the attention has been focussed on how this will affect our dealings with the Socratic problem. However we should not forget that there is another group of dialogues which do seem to offer some critical view of the theories proffered in the Republic (as Kahn and Annas would, I think, both concede). The Parmenides is the most notable example, but the Sophist and the Philebus would do as well. So the question at issue may be this one: just how self-critical should we suppose Plato to be?

There is a different issue here which will be addressed in part in what follows: whether it is worth asking questions about the order of the dialogues at all. John Cooper has mounted a robust attack on our chronological obsessions []ㅡ, and it is surely right to complain that chronology should not take over from our readings of individual dialogues, nor from our attempts to understand what the dialogues say, rather than when they said them. It is equally true that any attempt to arrange the dialogues in terms of their relative philosophical sophistication is just daft (I admit it) - who is to say that Plato got cleverer? - even although it is worth noticing, if nothing else, thematic continuities between dialogues. But I speak here of something more specific: actual intertextual references whose direction and purpose needs to be determined.

Let me offer an example, taken from the dialogues with which much recent debate has been concerned: a notorious cross-reference between the Euthydemus and theRepublic. At Euthydemus 288c ff. Socrates and Cleinias have agreed that they should philosophise. For this is to acquire knowledge, and knowledge (or wisdom), they have agreed, is the only good itself by itself. But they find it hard to identify what knowledge this is; and so they cast about amongst the arts and crafts (the technai). When Socrates suggests the art of generalship, Cleinias rejects it, on the grounds that it is merely a hunting skill. Cleinias - hitherto a very unsophisticated interlocutor then makes a speech:

No art of hunting itself goes any further than the hunt and the capture; when once the huntsmen lay their hands on what they chased they are unable to put it to use. Instead, huntsmen and fishermen turn their catch over to the cooks; while geometers and astronomers and calculators - for these are hunters, too, since they don't make their diagrams, but discover what is already there [7] since they don't know how to use their catch, but only to hunt it, they hand their discoveries over to the dialecticians to use - at least, they do that so long as they are not completely unreasonable. (Euthydemus 290b-c)

The same, Cleinias adds, should be said of the generals: when they capture a camp they hand it over to the politicians. So it is among the users that they should seek the wisdom that makes us happy. 
It has frequently been pointed out that this passage is striking in its intertextual relation to the Republic [ㅈ] . First, not only do we have here a rare reference to the dialecticians (compare Republic 532b ff.), but dialecticians are contrasted with the possessors of those skills which in the Republic are preliminary to dialectic: calculation (522c ff.), geometry (526d ff.) and astronomy (527d ff.) [9]. Second, the thought that the objects of geometry, astronomy and calculation are discovered, not invented, is itself a running theme of the Republic, from 510 onwards. Third, the suggestion that these preliminaries to dialectic may hand their catch on to the dialectician 'so long as they are not completely unreasonable' seems to bear some relation to the division of the line into what is to do with perception and what is to do with reason $(509 \mathrm{~d} 8,510 \mathrm{~b} 2)$. But all this is not merely a brief reference to the Republic's training programme: consider two other features. First, as the aporiai start to bite, 293a, Socrates suggests that this has been the third wave of argument (compare Republic 472a, where the issue is whether philosophers might really become kings). Second, throughout the dialogue Socrates has made great play with the inadequacy of his old age for these intellectual pursuits (compare Euthydemus $272 \mathrm{~b}$ ff. with Republic 536c-d). The intertextuality between the Euthydemus and the Republic is, I take it, one that we should take seriously [10]. What is more, it is hard to make much sense of what Cleinias says otherwise. But what exactly are we to make of it?

Consider, first, the context in the Euthydemus. At 281e Socrates and Cleinias reach the conclusion that wisdom is the only good, itself by itself (auto kath hauto) and ignorance, itself by itself, the only evil. The scope of Socrates' claim has long been disputed: is wisdom is the only good, ever, anywhere, altogether? Or does Socrates merely mean that wisdom is the only intrinsic good, allowing for others, which are extrinsically valuable? [11] Whichever is meant, the preceding argument makes it clear that Socrates is not merely making the claim that wisdom is a good thing; or even that it is the best thing; or even that it is the only good thing. Instead, his argument turns on the thought that wisdom is responsible for our doing well whatever the other circumstances because wisdom is the source of goodness, ignorance the source of evil. [12] Wisdom, that is, makes what we may get valuable, and so is intrinsically valuable. Anything else valuable, if there is anything else valuable, gets its value by virtue of wisdom; if nothing else is valuable, then wisdom itself constitutes value [13].

This is strongly expressed (compare the Meno's reluctance to go this far, 88c), and in terms that we might suppose to have been annexed for transcendent forms (compare the 'itself by itself' locution at Phaedo $78 \mathrm{~d}$ or Parmenides 130b). But it is, nonetheless, hardly a thought with much content, at least at this early stage in the dialogue. What sort of wisdom are we supposed to be thinking about? How are we to think of wisdom in such a role? It cannot be the sort of wisdom to be found in effective practical reasoning, or in executive expertise - since that sort of wisdom would be valued derivatively, because of the ends which it enables us to pursue. What other kind of wisdom is offered here? It is true that the dialogue as a whole is supposed to be a protreptic to philosophy; and Socrates offers the conclusion that we should seek to be as wise as possible (282a6) and that we must philosophise (282d1). But there is not, or not yet, a clear account of what that would be, such that it is intrinsically valuable, and would give value to anything else that might be valuable too.

There follows an exchange with the two sophists, Euthydemus and Dionysodorus; and then at 288d Socrates returns to the exhortation to philosophise: the argument that follows, therefore, is explicitly linked to the preceding Socratic episode. But the next stage of argument, in which our passage appears, is puzzling; and its peculiar nature is emphatically marked in the way it is framed.

Socrates and Cleinias, supposing philosophy to be the acquisition of knowledge, set about trying to identify the knowledge that has this intrinsic value. They do so by trying to identify its object. They reject various productive arts - moneymaking, medicine, making lyres - on the grounds that in these cases the making of the product is separate from its use. In all such cases, as Cleinias points out, the producer must hand the product over to the user, since questions of happiness should be a matter of use, not production. It becomes clear, in the course of the discussion, however, that neither Socrates nor Cleinias seem to have taken the point made in the earlier passage, that it is wisdom which explains the good, not its objects or its products which explain the value of wisdom.

So perhaps we should take seriously the heavy irony with which Socrates suggests that he had expected that the knowledge they sought would turn out to be the art of the speechmaker, since that is like the art of bewitching snakes (289d ff.). For such arts, of course, like their productive counterparts, derive their utility and their value from the ends they bring about, and not the other way about. Indeed, it is of a piece with such irony that when Cleinias rejects the claims of generalship, the outer frame of the dialogue suddenly intrudes. For Crito interrupts, asking, incredulously, whether Socrates is serious in suggesting that it was Cleinias who said this - if he did, he will need no education at anyone's hands. Some by-play follows between Socrates and Crito - about who actually said the crucial words: was it one of the higher powers? (291a6) - and this serves to accentuate the detail of Cleinias' speech and to underline its content. Why?

The argument to identify the art that will make us happy continues, now in the frame dialogue between Socrates and Crito. But it ends in disaster, since every time they propose some candidate, they end up either in a regress, or else they arrive back where they began. So in considering the kingly art (which is now identified with the art of politics) they inquire whether that is the cause of doing well in the state. But they are unable to specify what it does for us or to identify what good it confers. And yet they have agreed that the good is knowledge (292b); so the good conferred by the kingly art had better be knowledge. But then on whom is that knowledge conferred? Everyone? And what is its scope? Everything? Presumably, the good conferred should be the knowledge itself, and not its products (292d3-4). But then to specify that knowledge seems to be impossible ... and the argument falters. The sophists seize the stage. 
There are, for my present purposes, two different, but connected issues here. The first is a substantial argumentative one: how exactly is the argument offered in theEuthydemus related - from a logical point of view - to the philosophical programme of the Republic? Are the objections and problems attached to the specification of the wisdom that is good itself by itself resolved in the Republic? Or exacerbated by it? And this then provokes the second issue: in what direction - backwards or forwards - does the allusion work?

The Republic shares the agenda of the Euthydemus: to discover and explain the good. The Republic, we might say, follows the agenda in two directions. The first identifies what is good in itself and in its consequences (358a) with the rule of reason in the soul: justice or psychic harmony. Justice, that is to say, is self-evidently an end, independently of any other consequences: it is a final good. The second offers a metaphysical account of the source of goodness - the form of the good, good itself by itself(508e, compare 516b)and its relation to knowledge and wisdom. The good, as the unhypothesised beginning of everything that is known, is the object and the origin of knowledge or understanding (511b). [14] Understanding is, arguably, necessary and sufficient for the rule of reason in the soul. [15] The goodness of understanding, however, is dependent on the form of the good: understanding is good in itself (it is itself an end, without consideration of its consequences) but not itself by itself (not independently of its relation to some intrinsic good, something which is good itself by itself). [16]

The Euthydemus, on the other hand, claims that wisdom is an intrinsic good, good itself by itself. This seems to mean both that wisdom is itself a good and that it is the source of the goodness of any other goods there might be. But that thought, it might be said, is the complete opposite of the view offered in the Republic. For there the intrinsic good, though an object of knowledge, is the source of goodness independently of whether it is known. And indeed that claim is a central part of the metaphysical picture of the Republic, which insists - as does Cleinias on behalf of the geometers - that the objects of knowledge are eternal and transcendent; and that this feature of them is what explains their knowability. In this crucial matter, the Republic and the Euthydemus disagree.

A proleptic account might explain this easily: the Euthydemus starts us on the way to thinking about how wisdom might be an ethical end, by suggesting to us that it is the source of value. But that leaves wisdom with no content; the Republic rectifies that omission by specifying the content and the source of value, both external to understanding, as the form of the good.

Indeed, a metaleptic view might say much the same thing: the Republic criticises the limited conclusions of the Euthydemus and both alters and amplifies them in the grand vision of the constitution of understanding, and its place in the best life. So the direction of the allusion is backwards: the Republic focuses our attention on the Euthydemusby alluding, in the educational programme of book VII, to Cleinias' speech.

But now this begins to look rather implausible. Cleinias' speech is telegraphic, where Republic VII is discursive: we would expect, therefore, that it is the former which alludes to, and triggers reflection upon, the latter, and not the other way about. So is that prima facie evidence for prolepsis - for the claim that Cleinias' words anticipate the Republic, and the Republic's correction of them? [17] It is, unless we suppose that the order of the critique - and the order of the dialogues themselves - is reversed. It is, unless we suppose that it is the Euthydemus, not the Republic, which offers us critical reflection on its counterpart, so that the allusion in the Euthydemus refersback. [18]

Now this possibility may perhaps have some interest. Consider once again the critique of the arts and crafts, and their significance in ethics, offered by the Euthydemus. The first Socratic episode invites us to see that even the products of arts are themselves valueless (not, note, inaccessible: this is not an argument about getting goods, but about what constitutes them) without knowledge. So the conception of knowledge as an art or craft is directly rejected, in favour of an account which locates value in the state of the virtuous person. [19]

From an ethical point of view, this theory is insistently agent-centred. The second Socratic episode takes a different tack, and thinks about how we should think about arts and crafts in the political arena. If we seek someone to confer benefit upon us, who should it be? Each of the answers first suggested by the interlocutors runs into difficulties, because each of the answers fails to take the lesson of the first episode, that the only good itself by itself is wisdom. If the first episode insists on an agent-centred view of goodness, the second imagines how we should make such an agent-centred view cohere with what I shall call a technical conception of politics. Such a technical conception imagines the object of politics to be the conferral of benefits on a commercial or exchange model, not on an educative one. The end of politics, on such an account, is providing goods for the citizens, not making the citizens good. (Of course, this is to suppose, as should not be controversial, that wisdom cannot be transferred as a commodity, and that education is not an exchange). This view finds itself in difficulties, I suggest, just because the technical conception of the political art is inimical to an agent-centred view. As a consequence, it falls here to the very objection launched against things commonly supposed to be good in the earlier Socratic episode, that they lack an account of what their goodness is. What is more, even when knowledge itself is what the king confers, it invites a puzzle about distribution. This, in turn, provokes a regress, just because it understands goods as commodities, not as states of the agent's soul.

Suppose, then, that we take the aporetic conclusion of the second Socratic episode seriously - as well we might, since the aporia, differently diagnosed, is repeatedly pointedout - we may understand it as an attack on any easy analogy between wisdom and the arts, on the basis that the arts fail, themselves by themselves, to account of the value of their own objects. Where would this leave the relation between the Euthydemus and the Republic? 
As I suggested, one view would be that the Republic amplifies what the Euthydemus leaves unclear (the nature of wisdom). A quite different view might be that theRepublic's conception of both personal and political good is misguided. According to the Republic, although the rule of reason is good in itself, it is not good itself by itself. For the source of reason's goodness lies in the unhypothesised beginning, and so outside the virtuous agent. Understanding is good because of the reality that is understood, and not in itself. So there is nothing about the state of the agent which explains why this state is good for him; instead the goodness is transferred from the objects to the agent. This view seems - to many, at least - to miss something important about what understanding is. That Plato himself may have thought so too may be witnessed by his suggestion - in the Philebus, for example, $28 \mathrm{ff}$. - that it is the structure of understanding itself which constitutes its goodness.

A similar problem may arise for the philosopher-kings. The Republic supposes that their governance of the state maximises the benefit for the citizens. It does so by means of the kind of benevolent despotism which ensures that everyone is best provided for; but, famously, it pays little attention to the internal state of any citizens but the philosophers. The happiness of the citizens at large is a utility, not a virtue (see, for example, some of the more brutal provisions, 541a: virtue, after all, is the disposition of those in whom reason rules); and happiness is to be understood in terms of the effective provisions made by the despots (consider, for example, the description of the philosophers learning to manage in the dark, $520 \mathrm{~b} f f$.). In the politics of the Republic, that is to say, the analogy with the arts and crafts continues to hold sway, even where Plato's moral psychology has retreated from such crude consequentialism. But that may not be true of, say, the politics of the Politicus, where the virtues of the statesman are understood not in terms of utility but rather in terms of good and equitable judgement (294 ff.). In the Politicus the consequential provisions of the laws are a necessary evil, in the absence of the virtuous leader, and not themselves the good of the state (see the gloomy prognostications of $299 \mathrm{ff}$.). The task of the king, conversely, is to unify the state itself - to make the state a virtuous whole (305d). En route to that view, I suggest, lies the critique of the Republic launched by Socrates' conversation with Cleinias. This critique refuses to explain what is good in itself in terms of something outside itself, and shows that to offer such an explanation leads to empty regress.

So where does this leave the debate between prolepsis and metalepsis, between ingression and retrogression? The relation between the Euthydemus and the Republic that I have sketched is thoroughly controversial. To avoid metaleptic conclusions, and the developmentalism they might imply, the easy response is simply to deny this interpretation of what is going on in the Euthydemus (or, indeed, to deny either the pessimistic view of the Republic I have offered, or the optimistic view of the Politicus, or both). Even accepting those interpretations, prolepsis might have Plato revising in the Republic an argument which is aporetic and elliptical in an earlier work (that is, in theEuthydemus). So what I have suggested is an inconsistency would be merely an unclarity, waiting to be explained.

In response, I maintain that the difference between an ethical theory where the explanation of value is located in a state of the agent and one where it is located outside, is too radical for that story to be told. That is to say, between the two accounts of the good itself by itself in the Euthydemus and the Republic, the one where the good is internal to the agent, the other where it is external, there lies a genuine inconsistency, and one which is central to whatever we might suppose the grand plan to be. Such a case, as I suggested, is hostile to the proleptic view.

But even so - even if there is an inconsistency between the dialogues and even if the view offered by the Euthydemus is one which the modern eye might find more enlightened or progressive - this tells us nothing about the order of reading, nor the order of writing, of the two dialogues. That claim, rather, rests on what we might think of as a literary plausibility: that the elliptical words of the Euthydemus do indeed refer to the Republic; but that this ellipse can only fit with reasonable expectations of the reader, if it refers backwards. If that is conceded, and if we may find a view of wisdom or understanding as good itself by itself in dialogues themselves otherwise critical of the Republic, [20] then perhaps the critical reading of the Euthydemus, and not the ingressive one, may win the day. [21]

\section{MARY MARGARET McCABE}

King's College London.

UK.

bibiographie

AnNAS, J., 'Virtue as the Use of other Goods', in Virtue, Love and Form, eds. T. IRwIN and M. Nussbaum, Edmonton, 1994.

AnNAs, J., Platonic Ethics Old and New, Cornell, 1999.

Beversluis, J., Cross-Examining Socrates: A Defense of the Interlocutor in Plato's Early Dialogues, Cambridge, 2000

Burnyeat, M.F., 'Plato on how to speak what is not: Euthydemus 283a-288a' in CANTO-SPERBER, M. and PELLEGRIN, P. eds., Festschrift for Jacques Brunschwig, Belles Lettres, Paris, 2002.

COOPER, J. M., Plato : Complete Works, Indianapolis, 1997.

Decleva CAizzi, F., Platone: Eutidemo, Milan, 1996.

GiLL, C., 'Colloquium Report' in Plato 1, http://gramata.univ-paris1.fr/Plato/article13.html 
GiLl, C., 'Protreptic and Dialectic in Plato's Euthydemus', in Plato: Euthydemus, Lysis, Charmides, eds. T.M.RoBINSON and L. BRISSON, Sankt Augustin, 2000.

IRwIN, T., Plato’s Ethics, Oxford, 1995.

KAHN, C.H., Plato and the Socratic Dialogue: the Philosophical Use of a Literary Form, Cambridge, 1996.

KorsgaARD, C., ‘Two Varieties of Goodness', Philosophical Review 92, 1983.

Long, A.A. 'Socrates in Hellenistic Philosophy', in Stoic Studies, Cambridge, 1996.

McCABE, M.M., 'Indifference Readings: Plato and the Stoa on Socratic Ethics', in Classics in Progress: Essays on Ancient Greece and Rome, ed. T.P. WisEMAN, British Academy, forthcoming.

McCabe, M.M., Plato and his Predecessors: the Dramatisation of Reason, Cambridge, 2000.

Vlastos, G., Socrates, Ironist and Philosopher, Cambridge, 1991.

Footnotes

[1] C.H. Kahn, Plato and the Socratic Dialogue: the Philosophical Use of a Literary Form (Cambridge 1996), J. Annas, Platonic

Ethics Old and New (Cornell 1999).

[2] G. Vlastos, Socrates, Ironist and Philosopher (Cambridge: 1991), ch. 4.

[3] See, recently, J. Beversluis, Cross-Examining Socrates: A Defense of the Interlocutor in Plato's Early Dialogues (Cambridge 2000).

[4] See n. 1 above.

[5] My thanks to Verity Harte for insisting on this point.

[6] J.M. Cooper, Introduction to Plato : Complete Works (Indianapolis 1997), xii-xviii.

[7] The sense of this is obscure: does Cleinias mean that the geometers find existing diagrams, or that they investigate reality instead of making diagrams? Fernanda Decleva Caizzi (Platone: Eutidemo Milan 1996, p. 76, n. 61) comments that the obscurity is probably deliberate. That is grist to my mill, since such an ambiguity, along with the startling suggestion that it may involve (that geometers find diagrams out there) itself increases the self-consciousness of the passage.

[8] Strikingly by Myles Burnyeat, whose account of this passage (given in a seminar many years ago) first provoked me to think about it. See now M.F. Burnyeat, 'Plato on how to speak what is not: Euthydemus 283a-288a' in M.Canto-Sperber and P. Pellegrin, eds, Festschrift for Jacques Brunschwig, Belles Lettres, Paris, 2002.

[9] Notably omitted from Cleinias' list is the subject which Socrates goes to great pains to include at Republic 528, stereometry. [10] Vlastos, Socrates 128 suggests merely that the Euthydemus' language provides us with evidence for Plato's abandoning the elenchus in favour of the study of mathematics. For Kahn's more sustained reading, see n. 17 below.

[11] See here C. Korsgaard, 'Two Varieties of Goodness', Philosophical Review (92) 1983, 169-95. My attention was first called to this puzzle about the intrinsic good in Plato by Bernard Williams, in a Keeling lecture on the Republic which I hope will soon appear in print.

[12] This claim requires more argument than I can offer here: I defend it in 'Indifference Readings: Plato and the Stoa on Socratic Ethics' in T.P. Wiseman, ed., Classics in Progress: Essays on Ancient Greece and Rome (forthcoming: British Academy). See also Annas,'Virtue as the Use of other Goods', in Virtue, Love and Form, eds. T. Irwin and M. Nussbaum (Edmonton 1994) 53-66; T. Irwin, Plato's Ethics (Oxford: 1995), 251-64; A.A.Long, 'Socrates in Hellenistic Philosophy', in Stoic Studies (Cambridge 1996), 134; C. Gill, 'Protreptic and Dialectic in Plato's Euthydemus', in Plato: Euthydemus, Lysis, Charmides (Sankt Augustin 2000) eds. T.M.Robinson and L. Brisson, 133-143.

[13] Such a claim about the intrinsic good, where what is good itself by itself is supposed (also) to be good should be distinguished from other causal/explanatory accounts: for example, a machine for making cars is responsible for the cars it makes, but it is not a car, and we should not claim, either, that it is a car 'itself by itself'.

[14] The identification of the form of the good with the unhypothesised beginning is, inevitably, controversial, since it is not explicit. I think that the parallel with theEuthydemus may, in fact, help to defend the identification; but I have no space to develop the point here. On current interpretations of the good see [C. Gill 'Conference Report' in Plato Issue One.->13

[15] Necessary because understanding is that whereby reason rules; sufficient because once the soul has reason, reason rules.

[16] See again Korsgaard (n. 11 above).

[17] See Kahn, n. 1 above 61, 307-9.

[18] Stylometric tests may suggest otherwise; I continue to maintain that Plato's artistry could produce pastiche of his own earlier works.

[19] Contra Irwin, loc.cit.

[20] As I have argued, Plato and his Predecessors: the Dramatisation of Reason (Cambridge 2000), chs 5-6. 7-8.

[21] I should like to record my thanks to Christopher Gill, for provoking me to write this; and to Verity Harte and Amber Carpenter for their customarily incisive comments on an earlier draft. 